\title{
耕地资产社会保障功能的空间分异研究 不同农业类型区的比较
}

\author{
王亚辉 ${ }^{1,2}$, 李秀涁 3,4 , 辛良杰 ${ }^{3}$, 谈明洪 3,4
}

(1 .西南大学地理科学学院,重庆 400715; 2. 西南山地生态循环农业国家级培养基地, 重庆 400715; 3. 中国科学院地理科学与资源研究所,北京 100101；4. 中国科学院大学,北京 100049)

\begin{abstract}
摘 要: 在中国人多地少和土地产权二元结构背景下, 耕地资源一直是农民的“命根子”, 其社会保障功能被认为是 社会的稳定器, 但近年来这一观点受到越来越多的质疑。目前中国农户耕地的社会保障功能还有多大, 迫切需要 利用详实的数据进行系统性、定量化的测算。基于此, 把拥有承包权的耕地看作农户的一项资产, 论文选取都市农 业区、集约农业区、平原主粮作物区和山地主粮作物区 4 类典型农业区, 实地调查 1025 户农户家庭, 旨在揭示耕地 社会保障功能的空间分异规律。结果表明: 作为家庭农业的生产资料, 耕地投入农业生产所获收益占家庭总收人 的比重在各区最高为 $50 \%$, 其中山区不足 7\%; 作为一项养老保障, 家庭耕地资产收益对养老需求的贡献率均不足 $30 \%$, 山区甚至不及 $3 \%$; 作为金融抵押品, 若以 20 万元资金需求为例,户均耕地资产可贷款额度均不超过资金需求 的 $20 \%$, 而山区仅为 $1 \%$ 。现阶段农户耕地资产的社会保障价值已十分微弱, 这有助于给出对新时期农村土地保障 功能的科学判断。随着城镇化的推进, 不同农业类型区农户的耕地收益及资产价值均不断下降, 尤其是在农地利 用边际化胁迫下的山区, 如何减缓山区耕地弃耕撂荒和耕地资产贬值, 无疑是乡村振兴战略实施过程中需要重点 关注的问题。
\end{abstract}

关 键 词: 社会保障功能; 农业类型区; 耕地资产; 空间分异;农地边际化

由于中国人多地少, 自 20 世纪 80 年代以来, 耕 地资源一直被认为是农民的“命根子”, 耕地资源的 社会保障功能被认为是中国城市化和工业化发展 过程中的稳定器和压舱石 ${ }^{[1]}$ 。其大致可概括为, 农 地对于农民最基本的功能就是社会保障功能、土地 是 8 亿农民的社会保障等。已有研究报道, 2000 年 以前, 耕地作为一项家庭资产确实对农民的就业和 养老起到保障作用, 依靠自家承包地, 农户能获得 农村户均收人和满足家庭基本消费 ${ }^{[2]}$ 。可以说, 耕 地社保论在当时甚至在当前仍然得到政界和学界 较为普遍的认同 ${ }^{[3-5]}$ 。
随着城市化和工业化的不断推进, 农民的收人 和消费均呈现大幅增长的趋势, 从耕地中获取的收 益在农村居民收人中的占比越来越低。耕地的“命 根子”假说受到越来越多的质疑, 并受到更多的争 论 ${ }^{[6-7]}$ 。其主要观点包括: 种地养活自己不能算社会 保障, 仅仅在土地收益基础上的社会保障肯定不 高, 土地日益成为最低生活保障在不断弱化和土地 保障逐渐成为 “负保障” ${ }^{[6-8]}$ 等。然而, 这些学者尚未 采用详实的数据和科学的方法给予论证, 这可能是 目前耕地社保论仍然被大家所认可的原因 ${ }^{[9-10]}$ 。

事实上, 耕地社会保障功能的大小, 取决于农

收稿日期 : 2019-08-08; 修订日期 : 2019-11-20。

基金项目: 国家自然科学基金青年项目(41901232); 国家自然科学基金重点项目(41930757); 教育部人文社会科学研究青年基 金项目(19XJCZH006); 重庆市社会科学规划项目(2018BS59); 中央高校基本科研业务费专项资金项目 (swu118054)。[Foundation: National Natural Science Foundation of China, No. 41901232; Key Projects of the National Natural Science Foundation of China, No. 41930757; Youth Fund for Humanities and Social Sciences Research of the Ministry of Education, No.19XJCZH006; Chongqing Social Science Planning Project, No. 2018BS59; Fundamental Research Funds for the Central Universities, No. swu118054. ]

第一作者简介: 王亚辉(1989-), 男, 安徽毫州人, 博士, 副教授, 研究方向为土地利用变化。E-mail: wangyhui.15b@igsnrr.ac.cn 1473-1484. [Wang Yahui, Li Xiubin, Xin Liangjie, et al. Spatial differentiation of social security function of cultivated land assets: Comparison of different agricultural regions. Progress in Geography, 2020, 39(9): 1473-1484. ] DOI: 10.18306/dlkxjz.2020.09.005 
户耕地的资产价值。近年来山区坡耕地弃耕、撂荒 和零租金流转等现象在全国范围内较为普遍 ${ }^{[11-18]}$ 。 1992-2017年, 全国范围内有耕地撂荒记录的县市 达到 165 个, 主要集中在湖北、重庆、甘肃、云南、四 川、江西和安徽南部等地区 ${ }^{[1]}$; 基于全国山区县的 抽样调查显示, 2014-2015 年, 78\%的村庄出现了 耕地撂荒, 耕地撂荒率为 $14.3 \%{ }^{[11-14]}$ 。与此同时, 山 区耕地零租金流转的比例已超过 $70 \%{ }^{[15,17-18]}$ 。以上 现象说明山区的耕地资产价值出现了贬值。那么, 当前全国不同地域范围内是否均出现了耕地资产 贬值现象, 这对农户耕地资产的社会保障功能又有 多大的影响? 对于这些问题, 无疑需要采用详实的 数据进行系统性和定量化的测算。

现实生活中, 对于农户而言, 耕地资产的社会 保障功能主要包括:第一, 农民务农的生产资料, 具 有解决农民就业的保障; 第二, 居民养老保障, 即当 农民退休或年龄较大无法从事农业生产时, 转出耕 地获得租金以维持老年人的日常消费; 第三, 金融 抵押功能, 即把耕地作为抵押品向金融机构申请贷 款的抵押贷款作用。鉴于此, 本文把拥有承包权的 耕地看作农户的一项资产, 选择 4 种主要农业类型 区作为案例: 都市农业区、集约农业区、平原主粮作 物区和山地主粮作物区, 较全面地评估耕地的社 会保障功能, 以期为农村土地政策调整提供有益 参考, 同时给出新时期农村土地保障功能大小的 科学判断。

\section{1 数据来源与研究方法}

\section{1 数据来源}

1.1.1 不同农业区的调研数据

(1) 调研与数据收集

由于区域之间耕地利用方式的差异, 本文选择 4 种农业类型区以揭示不同土地利用方式下耕地社 保功能的空间分异特征。按照耕地利用方式把农 业细分为都市农业区、集约农业区、平原主粮作物 区和山地主粮作物区, 农业类型比较齐全, 能够较 全面地代表全国的农业类型特征。4个农业类型区 的概况如下: (1) 都市农业是指大中城市经济圈内或 都市郊区, 以服务城市发展需求而发展起来的现代 农业, 比如生态农业和观光农业等。其中北京市大 兴区、通州区和顺义区的部分农业是都市农业的典 型代表, 都市农业发达、耕地利用价值相对凸显, 能
够代表大城市和特大城市周边耕地的利用状况。 (2) 集约农业是指在一定量的耕地上,投入较多的劳 动和生产资料,并采用先进的技术和管理手段以增 加产出, 比如大棚蔬菜和温室花卉等。本文选取山 东省寿光市、青州市和昌乐县作为典型代表, 这 3 个 地区以经营大棚蔬菜和瓜果为主,农业集约利用程 度较高。(3) 平原主粮作物区是指在平原地区种植 的主粮作物,一般为国家粮食主产区, 比如种植水 稻和小麦等。这里选取湖北省监利县和洪湖市, 它 们地处江汉平原, 以种植主粮作物水稻为主, 代表 平原地区粮食主产区的耕地利用水平。(4) 山地主 粮作物区是指在山区经营的种植业, 比如玉米和红 薯等。这里选取重庆市武隆区和西阳县, 这 2 个地 区为西南典型山区县, 耕地资源相对丰富, 能够代 表山区坡耕地的农业经营特征。

农户选取遵循以下分层抽样原则: 根据耕地利 用类型和地形差异,选取北京市、山东省、湖北省和 重庆市作为典型案例区, 分别代表都市农业、集约 农业、平原主粮作物和山地主粮作物 4 种农业类型; 根据案例区的经济发展、种植业结构和地理特征, 在每个省市内选取 2 3 个典型县市, 共计 10 个县 市; 根据乡镇的人均收人水平和农业发展状况, 从 每个县市内篮选 2 4 个乡镇, 共计 24 个乡镇; 同时 在每个乡镇内选取 3 6个自然村, 共计 84 个村; 按 照自然村人口规模, 从各村内随机抽取约 10 30户 农户进行调查, 调查方法采用参与式农村评估法 (Participatory Rural Appraisal, PRA)中的半结构式 访谈 ${ }^{[19-20]}$, 其中户主作为主要被访谈人, 其他家庭成 员辅助回答, 每份问卷大约用时 $2 \sim 3 \mathrm{~h}$ 。调研包括 4 个省市、10个县市、24个乡镇和 84 个自然村, 共计 农户问卷 1025 份(表 1 )。其中村问卷和住户问卷分 别涉及可用变量 76 和 253 个。调研于 2017 年 710 月, 历时近 4 个月。每个案例区前期调研人员培 训 $1 \mathrm{~d}$, 预调研 $2 \mathrm{~d}$,正式调研 7 10 d。

(2) 调研数据修正与处理

调研问卷包括村问卷和住户问卷 2 种类型, 其 中村问卷的调查对象是村支书、会计或了解村内实 际情况的其他干部, 内容包括村内人均收人、土地 确权、土地流转、劳动力工资和社会保障等信息。 住户问卷的调查对象是农业经营户, 内容包括家庭 人口信息、土地利用(包含土地流转)、家庭生产经营 和收支等情况。这些指标能够满足研究需要, 但不 同地区可能遇到标准亩和实物量等度量标准差异, 
表 1 案例区农户调查基本情况

Tab.1 Basic information of households in the case study areas

\begin{tabular}{llcccc}
\hline \multicolumn{1}{c}{ 农业区 } & \multicolumn{1}{c}{ 调研区域 } & 调研村/个 & 农户/户 & 有效农户/户 & 有效问卷率/\% \\
\hline 都市农业区 & 北京市大兴、通州和顺义区 & 23 & 234 & 204 & 87.18 \\
集约农业区 & 山东省寿光市、青州市和昌乐县 & 19 & 202 & 172 & 85.15 \\
平原主粮作物区 & 湖北省监利县和洪湖市 & 24 & 287 & 257 & 89.55 \\
山地主粮作物区 & 重庆市武隆区和西阳县 & 18 & 302 & 272 & 90.07 \\
合计 & & 84 & 1025 & 905 & 88.29 \\
\hline
\end{tabular}

因而需对数据进行修正。(1) 标准亩换算。部分地 区尚未完成土地确权,耕地面积仍按照当地的自然 条件或测量习惯丈量, 导致地区间耕地计量单位不 同, 比如湖北省多以大亩计量, 1 大亩等于 1.5 标准 亩 $\left(1\right.$ 标准亩 $\left.=666.67 \mathrm{~m}^{2}\right)$; 重庆市以挑计量, 1 挑等于 0.25 亩。因而需要把这些单位换算成标准亩,才能 核算单位耕地资产价值。2 实物量与货币量的换 算。家庭经营投人、耕地流转租金和消费等绝大多 数采用货币计量, 但少数地区仍有实物交换, 比如 重庆市西阳县农户之间经常互换种子种苗, 耕地租 金以粮食支付和施肥多采用畜禽粪便等。为了提 高区域间耕地资产价值的可比性,有必要把实物量 折算成货币量。折算的方法是亩均种子费用以当 地亩均所需的平均值替代; 农家肥以当地干粪和清 粪的当年售价换算, 其中干粪 0.5 元 $/ \mathrm{kg}$, 清粪为 20 元/t; 耕地流转租金按照粮食的当年价格进行折算, 即亩均租金=粮食数量 $\times$ 粮食单价。

\subsection{2 其他统计数据}

各年份价格指数、农业劳动力和国家支农投资 数据来自《中国统计年鉴》和《中国农村统计年鉴》, 用于估算耕地资产的生产资料价值; 农村居民患病 率来自《中国卫生统计年鉴》,用于核算农村居民人 均养老需求; 一年期银行存款利率和农业税税率分 别来自《中国金融统计年鉴》和《中国财政统计年 鉴》,用于核算多年期耕地流转租金的现值。

\section{2 研究方法}

\subsection{1 耕地作为生产资料价值的测算}

一般而言, 耕地收益的高低直接决定农户家庭 的生活水平, 这使得考虑的问题被大为简化, 耕地 作为生产资料价值是指农户拥有承包权的耕地经 营收益用于支撑家庭生计的作用 ${ }^{[3]}$ 。本文采用耕地 经营收益占家庭总收人的比例来度量, 亩均耕地收 益的计算如下:

$$
R_{i}=P_{i} \cdot Q_{i}-I_{\mathrm{s}, i}-I_{\mathrm{p}, i}-I_{\mathrm{f}, i}-I_{\mathrm{m}, i}-I_{\mathrm{irr}, i}-I_{\mathrm{other}, i}
$$

式中: $R_{i}$ 表示农户第 $i$ 种农作物亩均耕地经营收益;
$P_{i} 、 Q_{i}$ 分别表示亩均耕地产量和农产品单价; $I_{\mathrm{s}, i} 、 I_{\mathrm{p}, i} 、$ $I_{\mathrm{f}, i} 、 I_{\mathrm{m}, i} 、 I_{\mathrm{irr}, i}$ 和 $I_{\mathrm{other}, i}$ 分别表示亩均种苗、农药、肥料、机 械、灌溉和其他物质投人,按照 2017 年农户实际投 人的货币量折算,单位为元/亩。农户耕地收益占家 庭总收人比例的计算公式如下:

$$
r_{j}=\sum_{i=1}^{k} q_{i} \cdot R_{i} / I_{\mathrm{total}, j}
$$

式中: $r_{j}$ 表示第 $j$ 个农户承包耕地的经营收益占家庭 总收人的比重; $k$ 表示家庭种植作物种类; $q_{i}$ 表示某 种作物的面积(亩); $I_{\text {total }, j}$ 表示第 $j$ 个农户家庭全年总 收人。所涉数据均以 2017 年价格进行折算。

1.2.2 耕地作为养老保障价值的测算

家庭耕地的养老保障价值指当农民因年龄较 大而无法从事农业生产时,转出耕地获取租金以维 持老年人生活消费的作用。首先,需要核算耕地养 老保障价值; 其次, 需要估算农村养老需求下限和 上限; 最后测算耕地养老缺口, 进而给出农户耕地 资产对养老保障的支撑作用。

(1) 耕地养老保障价值

耕地养老保障价值等于人均承包耕地面积乘 以转出每亩耕地获得的租金,计算公式如下:

$$
\mathrm{LP}=\mathrm{CL} \cdot \mathrm{LR}
$$

式中:LP 表示人均耕地养老保障价值(元);CL 表示 人均承包耕地面积(亩); LR 表示农户转出耕地获得 租金(元/亩)。

\section{(2) 养老需求下限和上限}

养老需求是指与当前经济发展相匹配的、在适 度范围内的合理养老支出。养老需求下限是指农 村老年居民基本的生活开支，包括衣着、食品、居 住、交通通信和医疗费用等; 养老需求上限是在基 本生活消费的基础上,适度增加日常消费和娱乐支 出 ${ }^{[2]}$ 。养老需求下限计算公式:

$$
\mathrm{DP}_{1}=\gamma \cdot C_{1}+\rho \cdot(1-\eta) \cdot C_{2}
$$

式中: $\mathrm{DP}_{1}$ 表示农村人均养老需求下限; $C_{1}$ 表示家庭 人均基本生活需求,包括衣着、食品等; $\gamma$ 为老年人 
消费系数, 通过实地调查数据估算老年人均基本生 活消费约占农村人均消费水平的 $65 \%$, 故 $\gamma=0.65 ; C_{2}$ 表示农村居民人均医疗支出; $\eta$ 表示新型农村合作 医疗报销的比重，一般 $\eta=70 \% ; \rho$ 表示老年居民的患 病率, 数据来自《中国卫生统计年鉴》,农村老年人 患病率约为平均水平的 2 倍, 故 $\rho=2$ 。

养老需求上限的计算公式:

$$
\mathrm{DP}_{\mathrm{h}}=\gamma \cdot C_{1}+\rho \cdot(1-\eta) \cdot C_{2}+C_{3}+C_{4}
$$

式中: $\mathrm{DP}_{\mathrm{h}}$ 表示农村人均养老需求上限; $C_{3}$ 表示人均 老年人日常消费; $C_{4}$ 表示人均老年人娱乐支出。

(3) 养老需求下限和上限的缺口

养老需求下限的缺口是指养老需求下限减去 耕地养老保障价值和农村养老保险金; 养老需求上 限的缺口是指养老需求上限减去耕地养老保障价 值和农村养老保险金。养老需求下限缺口的计算 公式如下:

$$
\mathrm{GP}_{1}=\mathrm{DP}_{1}-\mathrm{LP}-\mathrm{SP}
$$

式中: $\mathrm{GP}_{1}$ 表示人均养老需求下限的缺口; $\mathrm{SP}$ 表示人 均农村养老保险提供的养老金。2009年以前以老 农保为标准, 2009年以后以新型农村社会养老保险 (以下简称新农保)为标准。2009年以前, 中西部老 农保基本养老金为 96 元/a, 即每月 8 元; 东部地区为 144 元/a, 即每月 12 元。2009年以后实行新农保, 相 应的养老金标准分别为: (1) 2009 年末年龄已到 60 岁的老年人, 只有基础养老金和地方政府补贴, 中 西部每人每年为 710 元, 即每月 55 元养老金和每年 50 元补贴; 东部每人每年为 760 元, 即每月 55 元养 老金和每年 100 元补贴 ${ }^{[2]}$; (2) 2009年末未满 60 岁的 老年人, 根据个人缴费标准进行发放,一般来说, 中 西部地区个人缴费额度为每人每年 100 元, 东部地 区为 300 元, 缴费年限需按 $15 \mathrm{a}$ 或补齐 $15 \mathrm{a} ; 60$ 岁以 后中西地区每人每年可领取养老金 840 元, 东部地 区每人每年可领取 1148 元, 当然各地区依据地方财 政能力和物价水平适当调整 ${ }^{[2]}$ 。

养老需求上限缺口的计算公式如下:

$$
\mathrm{GP}_{\mathrm{h}}=\mathrm{DP}_{\mathrm{h}}-\mathrm{LP}-\mathrm{SP}
$$

式中: $\mathrm{GP}_{\mathrm{h}}$ 表示人均养老需求上限的缺口。

1.2.3 耕地作为抵押功能价值的测算

2016年3月中国人民银行、中国银行业监督管 理委员会、中国保险监督管理委员会、财政部和农 业农村部联合发布《农村承包土地的经营权抵押贷 款试点暂行办法》, 该办法明确规定: 通过家庭承包 方式依法取得土地承包经营权或通过合法流转方
式获得土地经营权的农户及农业经营主体,均可按 程序向银行业金融机构申请农村承包土地的经营 权抵押贷款 ${ }^{[22]}$, 即政府对耕地赋予了金融抵押功 能。耕地资产的金融抵押功能是指农户把拥有承 包权的耕地作为抵押品向银行等金融机构申请贷 款的作用。图 1 呈现了户均耕地资产可获得贷款额 度的核算流程,首先核算抵押期限内可用于抵押耕 地的租金现值,其次通过抵押品折算系数核算出抵 押耕地的实际抵押价值, 最后通过抵押品贷款系数 核算出户均耕地的贷款额度。

可以作为抵押品的耕地租金现值的计算公式 如下:

$$
\mathrm{PVR}=\frac{\mathrm{LR}_{t}}{\tau} \cdot\left[1-\frac{1}{(1+\tau)^{t}}\right]
$$

式中:PVR 为农户可用于抵押耕地的租金现值; $\mathrm{LR}_{t}$ 为第 $t$ 年作为抵押品的耕地租金值; $t$ 为耕地可抵押 的期限, 表示为 $t=30-T_{t}-3$, 即 $30 \mathrm{a}$ 耕地承包期减去 已过期限 $T_{t}$ 和最后 $3 \mathrm{a}$ 期限(承包权到期的前 $3 \mathrm{a}$ 禁 止申请抵押贷款) $\tau$ 为耕地租金还原率,耕地还原率 由当地一年期限金融机构存款利率和农业税税率 决定。最终户均耕地贷款额度的计算如下：

$$
\mathrm{LL}=\rho_{1} \cdot \rho_{2} \cdot \mathrm{PVR}
$$

式中:LL 表示抵押耕地资产农户获得的贷款额度; $\rho_{1}$ 表示抵押品价值折算系数, 取值范围介于 $0.6 \sim 0.7$ 之间, 最大值可以取 0.7 。当 $\rho_{1}=0.6$ 时, 为耕地作为 抵押品贷款额度的下限; 当 $\rho_{1}=0.7$ 时,为贷款额度的 上限。 $\rho_{2}$ 表示抵押品贷款额度系数, 通过前期估算, $\rho_{2}=0.47$ 。

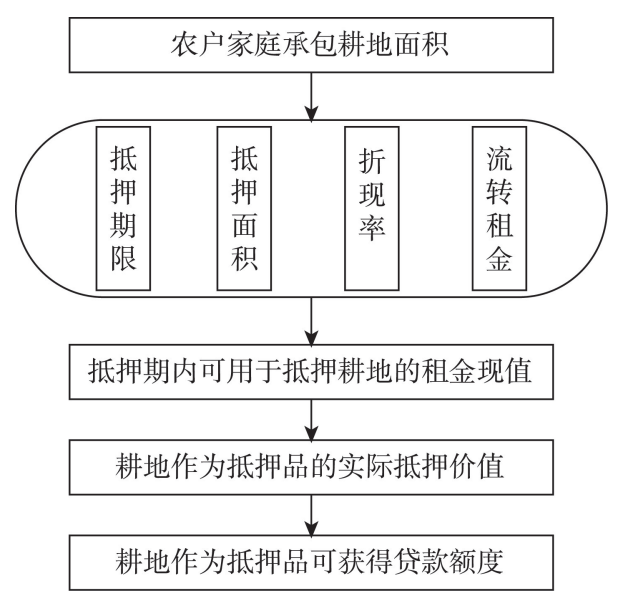

图 1 承包耕地可贷款额度的核算流程

Fig.1 Eligible loan amount calculation of contracted farmland as collateral 
2 农户耕地社会保障功能的区域分异 特征

在实证分析之前,需要摸清不同农业类型区农 户家庭的耕地资源禀赋。调查数据显示, 都市农 业、集约农业、平原主粮作物和山地主粮作物区户 均承包耕地面积分别为 5.09、7.05、10.91 和7.79亩, 人均承包耕地面积为 $1.52 、 1.81$ 、 2.49 和 1.87 亩。下 文分别从耕地作为生产资料、养老保障和金融抵押 3 个作用出发,揭示耕地社会保障功能的空间差异。

\section{1 耕地资产作为生产资料功能的区域差异}

调研发现,都市农业和集约农业区以种植蔬菜 瓜果为主,其中集约农业区蓅菜种植面积占比超过 $90 \%$; 而平原主粮作物和山地主粮作物区以种植主 粮作物(水稻和小麦)为主。表 2 显示, 4 种农业区亩 均耕地收益存在显著差异,都市农业、集约农业、平 原主粮作物和山地主粮作物区亩均耕地收益分别
为 $1484.75 、 7818.51 、 476.42$ 和 16.82 元, 其中集约农 业与山地主粮作物亩均耕地收益相差 400 余倍。

在此基础上,本文进一步核算了 4 种农业区户 均耕地收益和户均总收人。表 3 显示, 以 2017 年价 格估算,都市农业区、集约农业区、平原主粮作物区 和山地主粮作物区的户均耕地收益依次为 $11544.38 、 69672.96 、 14167.32$ 和 4071.63 元, 相对应 的户均总收人依次为 $111058.40 、 137332.80$ 、 135560.50 和 62252.34 元。4 种农业区户均耕地收 益占家庭总收人的比重分别为 $10.39 \%$ 、 $50.73 \%$ 、 $10.45 \%$ 和 $6.54 \%$ 。结果表明,不同农业类型区户均 承包耕地资产所创造的收益存在较大差异,其中集 约农业区耕地收益占比最大,而山区最小。

以上结果表明,现阶段仅依靠经营家庭拥有承 包权的耕地资产,已经无法达到当地农村户均收人 水平。那么, 对于纯农业经营户来说, 要想达到当 地农村户均收人水平,不同农业类型区户均需要经

表 2 不同农业类型区亩均耕地成本收益比较

Tab.2 Cost-benefit comparison of cultivated land per mu in different agricultural areas

(元/亩)

\begin{tabular}{|c|c|c|c|c|}
\hline 类别 & 都市农业区 & 集约农业区 & 平原主粮作物区 & 山地主粮作物区 \\
\hline 亩均产值 & 7111.24 & 15177.91 & 1027.24 & 909.25 \\
\hline 亩均成本 & 5393.64 & 7993.03 & 614.98 & 883.78 \\
\hline 种子种苗 & 2433.93 & 869.77 & 79.24 & 105.95 \\
\hline 农药 & 216.83 & 353.39 & 86.38 & 61.65 \\
\hline 化肥 & 423.85 & 1860.31 & 107.11 & 158.69 \\
\hline 灌溉 & 70.59 & 267.74 & 20.19 & 0.34 \\
\hline 机械费用 & 109.05 & 267.43 & 111.44 & 45.82 \\
\hline 地膜 & 28.04 & 44.61 & 3.03 & 5.35 \\
\hline 大棚 & 1177.97 & 2878.01 & 0 & 0 \\
\hline 劳动力 & 925.35 & 1446.51 & 204.05 & 503.18 \\
\hline 其他 & 8.03 & 5.25 & 3.55 & 2.79 \\
\hline 亩均利润 & 1717.59 & 7184.88 & 412.26 & 25.48 \\
\hline 加权后亩均利润" & 1484.75 & 7818.51 & 476.42 & 16.82 \\
\hline
\end{tabular}

注:数据来自 4 种农业类型区的实地调研,并经作者整理所得; *表示以农业区内各类农作物种植面积占比为权重,并按照此权重计算所 种植农作物的加权亩均利润。

表 3 不同农业类型区户均耕地收益与所需耕地面积比较

Tab.3 Comparison of yield from cropland and land area required per household in different agricultural areas

\begin{tabular}{cccc}
\hline 农业区 & $\begin{array}{c}\text { 户均耕地 } \\
\text { 收益/元 }\end{array}$ & 户均总收人/元 & $\begin{array}{c}\text { 实现当地农村平均收人户均 } \\
\text { 所需耕地面积/亩 }\end{array}$ \\
\hline 都市农业区 & 11544.38 & 111058.40 & 46.08 \\
集约农业区 & 69672.96 & 137332.80 & 14.82 \\
平原主粮作物区 & 14167.32 & 135560.50 & 199.39 \\
山地主粮作物区 & 4071.63 & 62252.34 & 119.72 \\
\hline
\end{tabular}


营多少亩耕地呢? 表 3 显示, 若达到当地农村户均 收人水平, 都市农业、集约农业、平原主粮作物和山 地主粮作物区户均所需耕地的面积依次为 46.08、 $14.82 、 199.22$ 和 119.72 亩, 其中平原主粮作物区所 需规模最大,而集约农业区最小。

值得注意的是, 近年来政学两界对农户最优的 耕地适度经营规模均有关注 ${ }^{[23-25]}$ 。基于湖南、江苏 和湖北等水稻作物区的调研显示, 家庭农场的规模 超过 200 亩便可达到当地户均收人水平, 同时种田 大户认为合适的家庭农场规模, 大抵在 200 500 亩。此外,2012 年全国户均经营 200 亩土地就可实 现当地户均收人水平, 该结论与本文在平原地区所 得结果较为一致,但其他农业类型区尚未涉及 ${ }^{[25]}$ 华南农业大学 “土地适度规模经营”课题组认为平 原地区户均最优面积为 88 117 亩 ${ }^{[24]}$; 中国科学院的 研究发现, 若要降低农户机械成本, 最优的农场规 模最小应为 50 亩 ${ }^{[25]}$ 。此外, 各地方政府的农业部门 也对耕地适度经营规模进行了测算, 以上海市为 例, 2015 年测算显示, 户均经营 100 150 亩便与当 地务工家庭收人基本持平。总之, 不同农业类型区 之间耕地作为农户生产资料的价值存在显著差异， 目前仅依靠农户拥有承包权的耕地很难达到农村 户均收人水平, 若农户未参与非农就业, 则必然需 要扩大家庭耕地规模 ${ }^{[26]}$ 。

\section{2 耕地资产作为养老保障功能的区域差异}

耕地养老保障价值等于人均承包耕地面积乘 以亩均流转租金。统计显示, 都市农业、集约农业、 平原主粮作物和山地主粮作物区亩均耕地流转租 金依次为 $1520 、 1137 、 255$ 和 63 元, 其中都市农业和 山地主粮作物区相差近 25 倍。与此同时, 各农业区 耕地的零租金流转比例同样存在显著差异, 其中山 区高达 $78 \%$, 其余地区较低,一般介于 $10 \%$ 20\% 之间。

表4 呈现了各农业区耕地养老保障价值。结果
显示,都市农业、集约农业、平原主粮作物和山地主 粮作物区人均耕地养老保障价值依次为 2310.51、 2058.17、637.74和 117.40元/a，说明不同农业类型区 下农户耕地的养老保障价值存在较大差异。从养 老需求看,统计显示, 4 个农业区人均养老需求的下 限依次为 $8825.77 、 6319.43 、 3960.49$ 和 3989.47 元/a, 同时人均养老需求的上限则依次为 9933.14 、 7454.23、4580.25 和 4810.88 元/a。可见, 都市农业 区和集约农业区人均养老需求较高, 而平原主粮作 物和山地主粮作物区相对较低。

对耕地养老保障价值的贡献率分析, 从养老需 求下限来看,各农业区耕地养老保障贡献率均不超 过 33\%, 其中集约农业区最高, 达到 32.57\%, 而山地 主粮作物区最低, 不足 $3 \%$; 从养老需求上限来看, 与 养老需求下限呈现类似的规律, 但各农业区的耕地 养老保障贡献率均有不同程度的下降,如集约农业 区降至 27.61\%, 都市农业区次之,山地主粮作物区 最低, 其贡献率仅为 $2.44 \%$ 。说明各地区人均耕地 资产作为养老保障远远无法支撑农民的养老需求， 目前山区尚不足以支撑其养老需求上限的 $1 / 40$ 。

图 2 呈现了典型农业区养老需求下限和上限的 缺口。从养老需求下限的缺口看, 都市农业、集约农 业、平原主粮作物和山地主粮作物区人均依次达到 6515、4261、3324和 3872元/a, 都市农业区缺口规模 最大,而平原主粮作物区最小; 从养老需求上限的缺 口看, 与下限的缺口存在类似规律, 同样都市农业区 的缺口规模最大, 人均高达近 7700 元 $/ \mathrm{a}$, 平原主粮作 物区最小, 人均缺口近 4000 元 $/ \mathrm{a}$ 。结果说明, 现阶段 耕地养老保障价值已无法满足养老需求,并且各农 业区耕地养老需求的缺口存在较大差异。

\section{3 耕地资产作为金融抵押功能的区域差异}

通过耕地作为抵押品可贷款额度的核算流程 (图 1), 计算户均耕地作为抵押品可获得贷款额度的 下限和上限(图 3)。结果显示, 从户均耕地可贷款额

表4 不同农业区人均耕地养老保障价值及其贡献率比较

Tab.4 Value of cropland per capita as old-age security and contribution rate in different agricultural areas

\begin{tabular}{|c|c|c|c|c|c|}
\hline \multirow[b]{2}{*}{ 农业区 } & \multirow{2}{*}{$\begin{array}{c}\text { 人均耕地养老 } \\
\text { 保障价值/(元/a) }\end{array}$} & \multicolumn{2}{|c|}{ 人均养老需求下限 } & \multicolumn{2}{|c|}{ 人均养老需求上限 } \\
\hline & & 数值/(元/a) & $\begin{array}{l}\text { 耕地养老保障 } \\
\text { 价值贡献率/\% }\end{array}$ & 数值/(元/a) & $\begin{array}{l}\text { 耕地养老保障 } \\
\text { 价值贡献率 } / \%\end{array}$ \\
\hline 都市农业区 & 2310.51 & 8825.77 & 26.18 & 9933.14 & 23.26 \\
\hline 集约农业区 & 2058.17 & 6319.43 & 32.57 & 7454.23 & 27.61 \\
\hline 平原主粮作物区 & 636.74 & 3960.49 & 16.08 & 4580.25 & 13.90 \\
\hline 山地主粮作物区 & 117.40 & 3989.47 & 2.94 & 4810.88 & 2.44 \\
\hline
\end{tabular}

注:数据来自 4 种农业区实地调研,经作者整理所得。 
度下限看, 都市农业、集约农业、平原主粮作物和山 地主粮作物户均耕地贷款额度依次为 39044 、 $40454 、 14078$ 和 2468 元, 最大值和最小值相差近 17 倍; 从户均耕地可贷款额度上限看, 4 个农业区户均

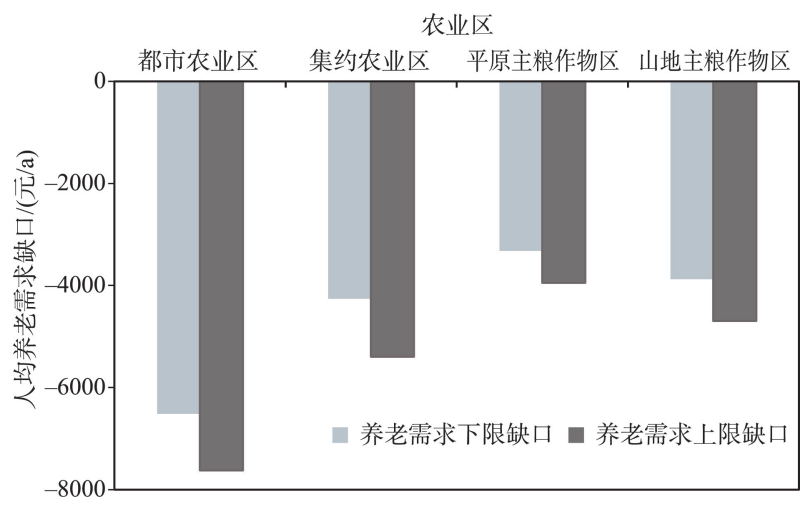

图 2 不同农业区人均养老需求的缺口

Fig.2 Gaps in the demand for old-age security per capita in different agricultural areas

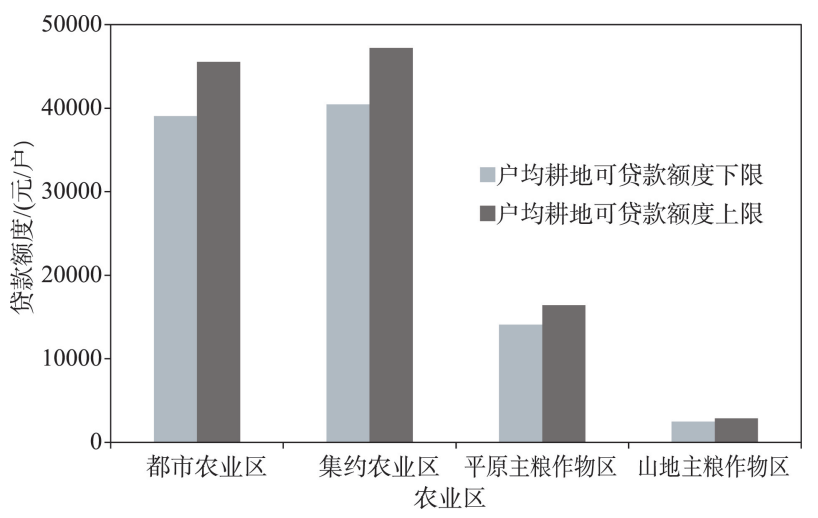

图 3 不同农业区户均耕地资产的抵押贷款额度

Fig.3 Eligible loan amount of cultivated land as collateral per household in different agricultural areas
贷款额度的区间介于 2879 47197元。可见,不同农 业区户均耕地可贷款额度之间存在显著差异。

那么, 耕地资产作为抵押品获得的贷款对农户 资金需求有多大贡献呢? 为了回答此问题, 这里设 置 2 种资金需求情景, 但为了使问题简化, 仅以户均 耕地贷款的上限为例进行分析。

情景 1 : 经营一个家庭农场所需投资。2012年 国务院印发《支持农业产业化龙头企业发展的意 见》, 多地规定当前农户土地经营规模相当于户均 承包耕地面积的 10 15 倍时, 户均收人与当地二三 产业务工收人基本相同。2015 年全国户均承包耕 地面积为 8.23 亩, 家庭农场规模在 82 124 亩为宜。 本文选取 100 亩作为家庭农场的规模, 按照 2015 年 主粮作物亩均收益 433 元, 100 亩耕地收益为 43300 元, 该值略高于全国农村户均收人(38034元)。

情景 2 : 经营一个小型畜牧业养殖场所需投 资。农户如果想进一步提高家庭收人, 如达到城镇 户均收人水平 $(90226$ 元/a), 其一, 农户可以继续租 进耕地以扩大经营规模,但会面临监工困难和管理 不善等规模不经济问题; 其二,农户可以从事畜牧 业养殖等其他经营主业。这里以养殖西门塔尔牛 为例, 10 个月出栏后每头牛平均获利 6000 元, 若养 殖 15 头牛, 年均收人可达到 9 万元, 与城镇户均收 人水平基本持平。

表 5 呈现了农户经营一个 100 亩农场所需的投 资, 按照当年市场价格, 所需种子、农药、化肥、灌 溉、机械、雇工和耕地租金等合计 97343 元, 约 10 万 元。同时,此表也呈现了经营一个小型畜牧业养殖 场的所需投资,按照当年价格,农户购买牛仔、建设 养殖场设施、置办养殖器具、牛病防疫投资和购买

表 5 经营家庭农场和小型畜牧场所需投入的成本

Tab.5 Input costs required to operate a family farm and a small livestock farm

\begin{tabular}{|c|c|c|}
\hline 类别 & 规模与费用 & 成本/元 \\
\hline \multicolumn{3}{|c|}{ 经营小型家庭农场所需成本(以 100 亩耕地为例) } \\
\hline 土地成本 & 需要租进 92 亩,亩均租金 261.64 元 & 24070.88 \\
\hline 其他成本 & $\begin{array}{l}\text { 其他要素的投人均按 } 100 \text { 亩的规模计算, 其中种子种苗 } 7884 \text { 元、农药 } 7695 \text { 元、化肥 } 19577 \text { 元、灌溉 } \\
\text { 及机械花费 } 22817 \text { 元, 雇工 } 14400 \text { 元等, 共计 } 73272 \text { 元 }\end{array}$ & 73272.00 \\
\hline 合计 & - & 97342.88 \\
\hline \multicolumn{3}{|c|}{ 经营小型畜牧业养殖场所需成本(以养殖 15 头西门塔尔牛为例) } \\
\hline 牛仔 & 牛仔 15 头, 每头 2400 元 & 36000.00 \\
\hline 场所设施 & 户外场所 20000 元, 牛舍和饲料库 50000 元, 室内牛栏 20000 元 & 90000.00 \\
\hline 饲料及其他 & 养殖器具和病毒防疫 5600 元, 饲料包括粗饲料和精饲料合计 71100 元 & 767000.00 \\
\hline 合计 & - & 202700.00 \\
\hline
\end{tabular}

注:数据来自中国养殖网,并经作者整理所得。 
饲料等合计 202700 元,约 20 万元。

图 4 呈现了农户所需投资的资金缺口,其中都 市农业、集约农业、平原主粮作物和山地主粮作物 区户均资金缺口依次达到 54448、52803、83575 和 97121 元。如果仅依靠耕地作为抵押品向银行申请 贷款, 要获得 10 万元资金, 4 种农业类型区所需耕 地规模分别为 $11 、 15 、 66$ 和 271 亩。 4 种农业区户均 承包耕地面积占所需耕地规模的比重分别为 $45 \%$ 、 $47 \% 、 16 \%$ 和 $3 \%$, 其中山地主粮作物区的比重仅为 $3 \%$ 。若以 20 万元资金需求为例, 都市农业、集约农 业、平原主粮作物和山地主粮作物区的户均资金缺 口依次为 $154448 、 152803 、 183575$ 和 197121 元。若 仅依靠耕地向银行申请贷款, 4 个农业区所需抵押 的耕地规模分别为 22、30、132 和 542 亩,与此同时, 户均拥有承包权的耕地占所需耕地规模的比重分 别为 $22 \% 、 23 \% 、 8 \%$ 和 $1 \%$, 其中山区的比重最小。

\section{3 讨论}

\section{1 不同区域土地利用变化的认识}

城镇化和工业化的推进直接改变了不同地域 和时点上的人口分布格局, 土地供需状况和利用方 式也随之改变, 进而引起不同区域土地资产价值的 变化。大中城市郊区的农民, 依靠经营高附加价值 的都市农业及观光农业能够获得较高的收益, 而在 山区尤其是偏远山区, 耕地多处于闲置、零租金流 转甚至撂荒等状态, 耕地资产的价值微乎其微。对 不同农业区的分析表明,都市农业区、集约农业区、 平原主粮作物区和山地主粮作物区的亩均耕地收 益分别为 $1485 、 7819 、 476$ 和 17 元, 其中集约农业区

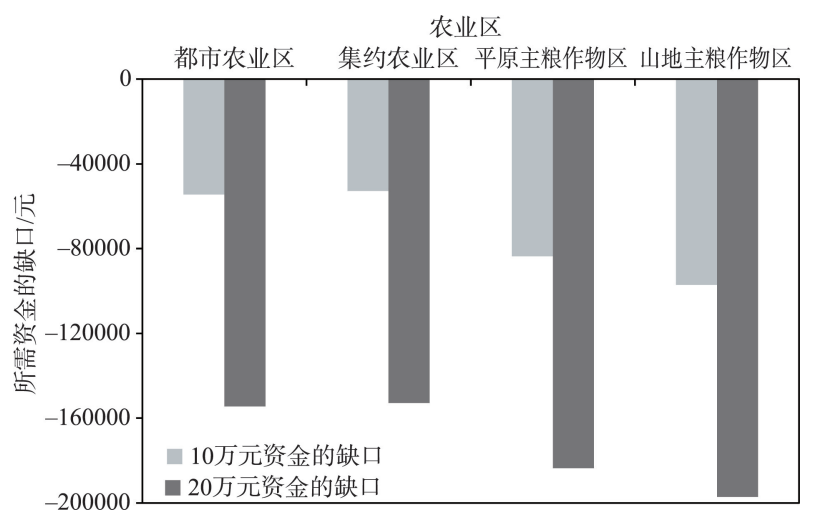

图 4 不同农业类型区户均所需资金的缺口

Fig.4 Gaps in fund per farming household in different agricultural areas
和山地主粮作物区的收益相差 400 余倍。

为了准确地刻画不同地域系统耕地收益演变 的规律, 本文把耕地利用系统简单划分为山区主粮 作物区、平原主粮作物区和城市郊区农业区 3 种类 型。图 5 呈现了1986-2017 年城市郊区、平原主粮 作物区和山区户均农业收益的比较。初期,城市郊 区、平原和山区户均耕地收益占 3 类家庭户均耕地 总收益的比例约为 $60 \% 、 20 \%$ 和 $20 \%$; 此后, 平原和 山区户均耕地收益的比例不断下降,而城市郊区的 比例则不断上升; 直到 2017 年, 山区耕地已处于亏 本状态, 平原户均收益仅占 $4.02 \%$, 城市郊区户均收 益则约占 $96 \%$ 。

随着城市化和工业化的推进, 大量农村劳动力 由农村转移到城市, 对不同地域的耕地利用产生显 著影响(图6)。对城市郊区而言, 人口集聚到城市增 加了对蔬菜和瓜果的消费以及对观光旅游的需求, 城市郊区的耕地由最初的传统农业逐渐向高附加 价值的都市农业和观光农业转型。对于平原和山 区而言, 农业劳动力的迁出使得农村劳动力出现短 缺, 非农务工工资的上涨传递到农业部门,农业劳 动力用工工价上升。在山区, 受地形复杂性和地块 破碎化的影响,农民很难使用机械等省工性工具替 代“昂贵”的劳动力, 使得农业生产中劳动力成本居 高不下,农业收益不断下降, 反映到耕地上即耕地 零租金流转甚至弃耕撂荒 ${ }^{[27-28]}$ 。反观平原地区, 因 其地形平坦、地块连片,农民易于使用机械等省工 性工具替代劳动力, 可以购买农业服务以实现服务 规模化,或实现耕地规模化经营,农业收益仍然较

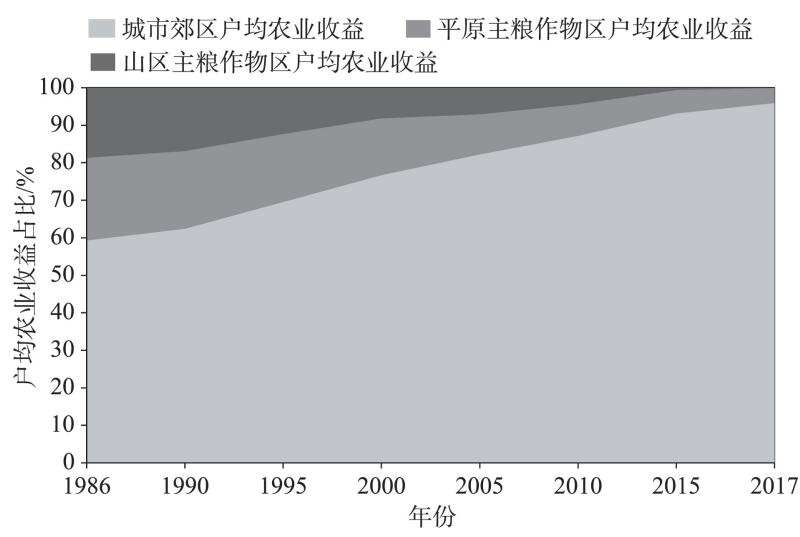

注:数据来源于农业农村部“农村固定观察点数据库”,并经作 者整理所得。

图 5 不同地域系统户均农业收益占比的变化

Fig.5 Changes in the proportion of agricultural income per household in different regions 


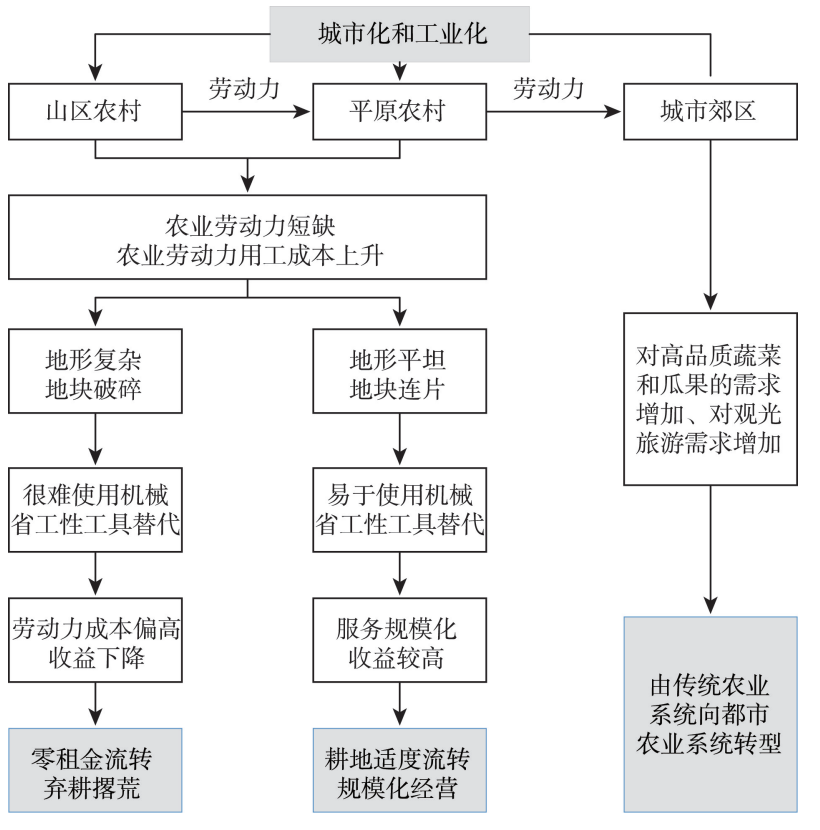

图 6 不同地域系统的耕地利用演变

Fig.6 Change of cultivated land utilization in different regions

高 ${ }^{[29]}$ 。随着城镇化的持续推进和山区人口的析出, 不同地域的耕地资产价值必然进一步分化,进而导 致农户收人和财富的分化, 如若长期持续下去, 必 将形成财富分配的马太效应。未来, 山区农地边际 化现象更加严重, 耕地资产价值逐渐“蒸发”, 山区 贫困问题和脱贫工作在短期内可能很难有效解 决。因此,当前如何减缓山区耕地撂荒和耕地资产 贬值, 无疑是乡村振兴战略实施过程中需要重点关 注的问题。

\section{2 研究局限与不足}

受平原造林影响, 北京市的样本可能无法准确 反映都市农业类型的特征。近年来北京市开展了 平原造林工程,现已形成两环、三带、九楔和多廊的 造林格局,而本文选取的大兴区和通州区均在平原 造林政策的实施区域内。政府租进农户的耕地开 展植树造林,亩均租金在 1500 2000 元,超过 70\%的 调研农户已参与平原造林工程, 因而调研样本可能 无法准确反映都市农业的特征。因而,接下来有必 要补充调查都市农业的农户样本, 以期准确揭示都 市农业区耕地的资产价值。此外,耕地的养老保障 功能并非完全通过转出耕地收益而实现, 很多情况 是通过家庭成员的耕种实现的。实际上, 依靠家庭 成员耕种实现的养老并非耕地资产的养老功能,而 应归属于家庭养老的范畴。这里涉及的耕地养老 仅仅是养老的一种形式, 通常以转出耕地获得收益
来实现。

值得一提的是, 从社会公共服务品的角度看, 耕地具有很强的正外部性和相应的保障功能。其 次, 从农村土地制度设置来看, “耕地命根子”说法 针对的是应急状态的考虑, 而不仅仅是本文认为的 耕地资产的社会保障功能。此外,本文研究的耕地 资产价值仅聚焦在生产资料、养老保障和金融抵押 3 种功能,除此之外,耕地资源的价值还包括从国家 获得的农业补占和耕地空间带给农民心里稳定预 期的价值等。还需要注意的是,耕地对农村居民的 承载力功能同样不容忽视, 比如虽然山区农村的耕 地出现了大量零租金或者撂荒的现象,但其仍然对 农村老年居民、留守儿童和妇女有一定的吸纳能 力。对于以上功能价值如何核算, 应是今后思考的 方向。

\section{4 结论与启示}

\section{1 研究结论}

本文把拥有承包权的耕地看作农户家庭的一 项资产，选取都市农业区、集约农业区、平原主粮作 物区和山地主粮作物区 4 种不同类型农业,通过实 地调研获得一手农户资料,系统测算了耕地作为生 产资料、养老保障和金融抵押 3 种保障功能的价值, 旨在揭示不同农业类型区耕地社会保障功能的分 异规律, 以期给出新时期耕地保障功能的科学判 断。主要结论如下:

(1) 从耕地作为生产资料的功能来看,都市农 业、集约农业、平原主粮作物和山地主粮作物区户 均耕地收益存在显著差异, 同时户均耕地收益占家 庭总收人的比重依次为 $10.39 \% 、 50.73 \% 、 10.45 \%$ 和 $6.54 \%$, 其中山区最低。当前,农户仅依靠拥有承包 权的耕地已无法维持家庭基本生计,若仍以农业为 经营主业,4种农业类型区户均所需经营的耕地面 积依次约为 $46 、 15 、 199$ 和 120 亩,才能达到当地农 村户均收人水平。

(2) 从耕地作为一项养老保障功能来看,都市农 业、集约农业、平原主粮作物和山地主粮作物区人均 耕地养老保障价值分别为 $2310.51 、 2058.17 、 637.74$ 和 117.40 元 $/ \mathrm{a}$ 。以养老需求下限为例, 4 种农业区人 均耕地养老保障价值的贡献率均不超过 $35 \%$, 其中 集约农业区最高, 为 $32.57 \%$, 山区不足 $3 \%$, 同时各 农业区的基本养老需求均存在较大缺口。 
(3) 从耕地作为金融抵押功能来看, 都市农业、 集约农业、平原主粮作物和山地主粮作物区户均耕 地作为抵押品的最大贷款额度介于 2879 47197元， 两者相差 10 余倍。以农户 20 万元资金需求为例, 仅依靠耕地作为抵押品向银行申请贷款, 4 种农业 区所需耕地面积依次为 22、30、132 和 542 亩, 同时 农户耕地资产占所需耕地面积的比重依次为 $22 \%$ 、 $23 \% 、 8 \%$ 和 $1 \%$ 。

\section{2 政策启示}

目前, 家庭拥有承包权的耕地资产已基本失去 了其原有的保障功能。现阶段农村居民的社会保 障必须建立在公共社会保障体系的基础之上,而不 能再过多地指望家庭拥有的少量承包耕地。耕地 “命根子” 的假说已失去了其基本论据, 以其来反对 耕地要素市场化改革已很难立足。当前, 家庭承包 耕地的社会保障作用十分有限, 这为放开土地承包 权的流转提供了契机。此外, 耕地承包经营权作为 金融抵押品, 金融机构难以处置, 而家庭承包耕地 资产的抵押贷款额度又普遍过低, 同样要求土地承 包权的适度流转。当然, 为防止土地集中和兼并, 地方政府对放开耕地承包权的流转要有序、适度地 进行。首先, 在市场准人上设置一定的限制, 比如 只允许耕地承包权在农户之间流转, 不允许城镇居 民参与; 其次, 参照城市房地产限购政策, 耕地承包 权可以先在县域范围内流转, 然后逐步扩大到地级 市或省域范围。

\section{参考文献(References)}

[1] 温铁军. 形成稳固的受惠群体: 关于农地制度创新的思 考 [J]. 中国土地, 2001(7): 14-16. [Wen Tiejun. To form a solid benefit group-thinking about innovation of farmland system. China Land, 2001(7): 14-16. ]

[2] 梁鸿. 苏南农村家庭土地保障作用研究 [J]. 中国人口科 学, 2000(5): 32-39. [Liang Hong. Research on the function of rural land security in southern Jiangsu Province. Chinese Journal of Population Science, 2000(5): 32-39. ]

[3] 蔡运龙, 霍雅勤. 中国耕地价值重建方法与案例研究 [J]. 地理学报, 2006, 61(10): 1084-1092. [Cai Yunlong, Huo Yaqin. Reevaluating cultivated land in China: Method and case studies. Acta Geographica Sinica, 2006, 61 (10): 1084-1092. ]

[4] 王成, 彭清, 唐宁, 等. 2005-2015 年耕地多功能时空演 变及其协同与权衡研究: 以重庆市沙坪坝区为例 [J]. 地 理科学, 2018, 38(4): 590-599. [Wang Cheng, Peng Qing, Tang Ning, et al. Spatio-temporal evolution and the syner- gy and trade-off relationship of cultivated land multi-function in 2005-2015: A case of Shapingba District, Chongqing City. Scientia Geographica Sinica, 2018, 38(4): 590599. ]

[5] 黄安, 许月卿, 刘超, 等. 基于土地利用多功能性的县域 乡村生活空间宜居性评价 [J]. 农业工程学报, 2018, 34 (8): 252-261. [Huang An, Xu Yueqing, Liu Chao, et al. Evaluation on livability of living space based on multiple functions of land use at county level. Transactions of the CSAE, 2018, 34(8): 252-261. ]

[6] 孔喜梅, 杨启智. 质疑农村土地的社会保障功能 [J]. 中 国土地, 2014(2): 1-2. [Kong Ximei, Yang Qizhi. Questioning the social security function of rural land. China Land, 2014(2): 1-2. ]

[7] 秦晖. 切实保障人地二权是土地流转的核心问题 [J]. 探 索与争鸣, 2014(2): 11-13. [Qin Hui. The core issue of land circulation is to guarantee the two rights of human and land. Exploration and Free Views, 2014(2): 11-13. ]

[8] 张宗亮. 我国农村土地流转若干问题研究 [J]. 山东社会 科学, 2010(4): 116- 121. [Zhang Zongliang. Study on some problems of rural land circulation in China. Shandong Social Sciences, 2010(4): 116-121. ]

[9] 程佳, 孔祥斌, 李靖, 等. 农地社会保障功能替代程度与 农地流转关系研究: 基于京冀平原区 330 个农户调查 [J]. 资源科学, 2014, 36(1): 17-25. [Cheng Jia, Kong Xiangbin, Li Jing, et al. The relationship between substitution degree of farmland social insurance function and farmland transfer-based on 330 peasant household surveys on the Jingii Plains. Resources Science, 2014, 36(1): 17-25. ]

[10] 唐炎, 张玲燕. 农地保障功能被替代程度地区差异及对 农户农地转出意愿的影响: 基于江苏省农户的调查 [J]. 农业现代化研究, 2015, 36(6): 1013-1019. [Tang Yan, Zhang Lingyan. Research on the differences of the substitution degrees of farmland security function among regions and their influences on farmer's willingness to transfer out farmland based on rural household survey data in Jiangsu Province. Research of Agricultural Modernization, 2015, 36(6): 1013-1019. ]

[11] 张学珍, 赵彩杉, 董金玮, 等. 1992-2017年基于荟萃分 析的中国耕地撂荒时空特征 [J]. 地理学报, 2019, 74 (3): 411-420. [Zhang Xuezhen, Zhao Caishan, Dong Jinwei, et al. Spatio-temporal pattern of cropland abandonment in China from 1992 to 2017: A meta-analysis. Acta Geographica Sinica, 2019, 74(3): 411-420. ]

[12] 李升发, 李秀涁, 辛良杰, 等. 中国山区耕地撂荒程度及 空间分布: 基于全国山区抽样调查结果 [J]. 资源科学, 2017, 39(10): 1801-1811. [Li Shengfa, Li Xiubin, Xin Liangjie, et al. Extent and distribution of cropland abandon- 
ment in Chinese mountainous areas. Resources Science, 2017, 39(10): 1801-1811. ]

[13] Li Shengfa, Li Xiubin. Global understanding of farmland abandonment: A review and prospects [J]. Journal of Geographical Sciences, 2017, 27(9): 1123-1150.

[14] Li Shengfa, Li Xiubin, Sun Laixiang, et al. An estimation of the extent of cropland abandonment in mountainous regions of China $[\mathrm{J}]$. Land Degradation \& Development, 2018, 29(5): 1327-1342.

[15] 王亚辉, 李秀涁, 辛良杰, 等. 中国土地流转的区域差异 及其影响因素: 基于 2003-2013 年农村固定观察点数 据 [J]. 地理学报, 2018, 73(3): 487-502. [Wang Yahui, Li Xiubin, Xin Liangjie, et al. Regional differences of land circulation in China and its drivers: Based on 2003-2013 rural fixed observation points data. Acta Geographica Sinica, 2018, 73(3): 487-502. ]

[16] 张英, 李秀涁, 宋伟, 等. 重庆市武隆县农地流转下农业 劳动力对耕地撂荒的不同尺度影响 $[\mathrm{J}]$. 地理科学进 展, 2014, 33(4): 552-560. [Zhang Ying, Li Xiubin, Song Wei, et al. Effect of agricultural laborer on cropland abandonment under land circulation at different levels in Wulong County, Chongqing City. Progress in Geography, 2014, 33(4): 552-560. ]

[17] 王亚辉, 李秀彬, 辛良杰. 山区土地流转过程中的零租 金现象及其解释: 基于交易费用的视角 [J]. 资源科学, 2019, 41(7): 1339-1349. [Wang Yahui, Li Xiubin, Xin Liangjie. Rent-free land transfer in mountainous areas and its explanation. Resources Science, 2019, 41(7): 13391349. ]

[18] Wang Y H, Xin L J, Zhang H Z, et al. An estimation of the extent of rent-free farmland transfer and its driving forces in rural China: A multilevel Logit model analysis [J]. Sustainability, 2019, 11: 1-17.

[19] Menconi M D, Grohmann D, Mancinelli C. European farmers and participatory rural appraisal: A systematic literature review on experiences to optimize rural development [J]. Land Use Policy, 2017, 60: 1-11.

[20] Yan J Z, Yang Z Y, Li Z H, et al. Drivers of cropland abandonment in mountainous areas: A household decision model on farming scale in Southwest China [J]. Land Use Policy, 2016, 57: 459-469.

[21] 位涛, 间琳琳. 中国农村土地养老保障贡献研究 [J]. 人 口与经济, 2014(1): 99-107. [Wei Tao, Yan Linlin. An empirical research on the endowment contribution of the rural land security in China. Population \& Economics, 2014(1): 99-107. ]
[22] 杨丹丹, 罗剑朝. 农地经营权抵押贷款可得性对农业生 产效率的影响研究: 以宁夏平罗县和同心县 723 户农 户为例 [J]. 农业技术经济, 2018(8): 75-85. [Yang Dandan, Luo Jianchao. The effect of mortgage availability of farmland operational right on agricultural production efficiency: Based on 723 households from Ningxia Pingluo and Tongxin. Journal of Agrotechnical Economics, 2018 (8): 75-85. ]

[23] 王亚辉, 李秀涁, 辛良杰, 等. 中国农地经营规模对农业 劳动生产率的影响及其区域差异 [J]. 自然资源学报, 2017, 32(4): 539-552. [Wang Yahui, Li Xiubin, Xin Liangjie, et al. The impact of farm land management scale on agricultural labor productivity in China and its regional differentiation. Journal of Natural Resources, 2017, 32 (4): 539-552. ]

[24] 李琴. 适度规模经营的最优区间范围如何测算 [J]. 农 村经营管理, 2017(7): 31. [Li Qin. How to calculate the optimal range of moderate scale operation. Rural Business Management, 2017(7): 31. ]

[25] Xu Y, Xin L J, Li X B, et al. Exploring a moderate operation scale in China's grain production: A perspective on the costs of machinery services [J]. Sustainability, 2019, 11: $1-17$.

[26] 刘灵辉, 刘燕. 家庭农场土地适度规模集中实现过程中 的博弯研究 [J]. 中国人口・资源与环境, 2018, 28(9): 150-157. [Liu Linghui, Liu Yan. A game-theory based research in the family farm to realize land moderate scale management. China Population, Resources and Environment, 2018, 28(9): 150-157. ]

[27] 刘成武, 李秀涁. 农地边际化的表现特征及其诊断标准 [J]. 地理科学进展, 2005, 24(2): 106-113. [Liu Chengwu, Li Xiubin. The character and diagnostic criterion for marginisation of the arable land. Progress in Geography, 2005, 24(2): 106-113. ]

[28] 何威风, 阎建忠, 周洪. 重庆市山区农户耕地转人特征 及其影响因素 [J]. 地理科学进展, 2014, 33(11): 15661576. [He Weifeng, Yan Jianzhong, Zhou Hong. Characteristics of farmland transfer- in and determinants in mountainous areas of Chongqing. Progress in Geography, 2014, 33(11): 1566-1576. ]

[29] 王亚辉, 李秀涁, 辛良杰. 农业劳动生产率的提高缩小 了农村居民收人差距吗? [J]. 自然资源学报, 2018, 33 (3): 372-385. [Wang Yahui, Li Xiubin, Xin Liangjie. Does the improvement of agricultural labor productivity shrink rural residents' income gap. Journal of Natural Resources, 2018, 33(3): 372-385. ] 


\title{
Spatial differentiation of social security function of cultivated land assets: Comparison of different agricultural regions
}

\author{
WANG Yahui ${ }^{1,2}$, LI Xiubin ${ }^{3,4}$, XIN Liangjie ${ }^{3}$, TAN Minghong ${ }^{3,4}$ \\ (1. School of Geographical Sciences, Southwest University, Chongqing 400715, China; 2. State Cultivation Base \\ of Eco-Agriculture for Southwest Mountainous Land, Southwest University, Chongqing 400715, China; \\ 3. Institute of Geographic Sciences and Natural Resources Research, CAS, Beijing 100101, China; \\ 4. University of Chinese Academy of Sciences, Beijing 100049, China)
}

\begin{abstract}
Under the background of a large population and scarce land resources and the dual structure of land property right, the cultivated land resources in China have been the lifeline of farmers, and their social security function is considered the stabilizer of society. But this view has been increasingly questioned in recent years. The capability of cultivated land as a security for farmers depends on its assets value. In the past few years, the phenomena of cropland abandonment and rent-free land transfer became increasingly prominent, indicating that the assets value of cultivated land in some areas has declined. Therefore, it is urgent to acquire detailed data in order to systematically and quantitatively examine the social security function of cultivated land assets for Chinese farmers. Taking the cultivated land with contracting rights as an asset for farmers, this study selected four agricultural regions (suburban agriculture, intensive agriculture, plain field agriculture, and mountain agriculture) and 1025 farming households in a survey to reveal the spatial differentiation characteristics of the social security function of cultivated land. The results show that: 1) As a means of production, there are significant differences in the yield from cultivated land assets in different agricultural regions. The proportion of the yield from cultivated land in household total income is no more than $50 \%$ and only less than $7 \%$ in mountainous areas. 2) For old-age security, there is also a big difference in different agricultural regions. The contribution rate of cultivated land as old-age security is less than $30 \%$, and it is less than $3 \%$ in mountainous areas. 3) With regard to its financial mortgage function, taking the 200000 yuan capital demand for a farming household as an example, the average eligible loan amount from cultivated land assets meets no more than $20 \%$ of this need, and only $1 \%$ in the mountainous areas. At present, the social security function of farmers' cultivated land assets is very limited, and the social security theory of cultivated land needs to be re-examined. This will help us to make scientific judgments on the rural land security function in the new era. With the continued advancement of urbanization, the yield and assets value of cultivated land for farmers show persistent differentiation in different agricultural regions, especially due to the marginalization of cultivated land in mountainous areas. How to slow the cropland abandonment and depreciation of cultivated land assets in mountainous areas needs to be researched during the implementation of the rural revitalization strategy.
\end{abstract}

Keywords: social security function; agricultural regions; cultivated land assets; spatial differentiation; land marginalization 